\title{
Editorial
}

\section{O monitoramento molecular dos linfomas $B$ maduros e as estratégias terapêuticas, convencional e de alta dose}

\author{
Carmino Antonio de Souza
}

A Revista Brasileira de Hematologia e Hemoterapia, neste número, traz uma importante revisão preparada pelo Prof. Marco Ladetto e seus colaboradores da Universidade de Turin, Itália, a respeito da relevância clínica do monitoramento molecular, através das técnicas de PCR, da Doença Residual Mínima nos linfomas B indolentes, particularmente, os linfomas foliculares. Como senso comum aos hematologistas e oncologistas, estes linfomas respondem ao tratamento citotóxico, mas não podem ser curados com estratégias de tratamento convencional (1-3). Apesar da quimiosensibilidade, a doença invariavelmente recai e, freqüentemente, surgem clones mais agressivos, resultando em evolução fatal.

A sobrevida é, geralmente, longa, podendo chegar a 15 anos, porém, estádios mais avançados resultam em sobrevida mais curta (4-7). Além disso, são linfomas que acometem pacientes mais idosos, quando comparados aos linfomas agressivos. Este cenário criou uma idéia de que tais linfomas são incuráveis, o tratamento quimioterápico é secundário, e visa, apenas, evitar ou retardar a progressão da doença. Porém, a introdução de terapêutica de alta dose, o transplante autólogo de medula óssea, inicialmente apenas nos pacientes recidivados ou em progressão de doença (8), pelo grupo do Dana Faber de Boston, trouxeram uma nova opção e podem ser vistas como cruciais para o amplo uso, particularmente, nos linfomas foliculares. Além disso, a utilização de marcadores moleculares, que sensibilizaram a detecção de doenças até o nível sub clínico, pode confirmar a importância deste método terapêutico, até então, apenas utilizado em linfomas agressivos (9-12).

Estes métodos permitiram ainda, confirmar a redução da doença abaixo dos níveis de detecção através do PCR e uma importância prognóstica (13-16). A introdução do purging in vivo, com a utilização de anticorpos humanizados específicos contra os linfócitos B, por exemplo o anti-CD20 (17-19) e in vitro com a utilização de colunas de seleção positiva ou negativa (20), foram outros fatores que trouxeram avanços relevantes na abordagem deste grupo de linfomas. Resta saber ainda, se este conjunto de estratégias diagnósticas, de monitoramento biológico e clínico, de terapêutica quimioterápica, auto-transplante e anticorpos específicos, combinadas em estudos prospectivos e controlados, trarão os resultados que todos nós esperamos nos próximos anos. Sabemos que a abordagem dos linfomas indolentes será o nosso maior desafio.

A cultura médica adquirida nas últimas décadas, em relação aos linfomas agressivos, não foi a mesma em relação aos indolentes. A distância entre o watch-and-wait e os transplantes de medula óssea é muito grande e encontrar os grupos certos para os tratamentos certos, nos linfomas indolentes, nos desafia e nos estimula. As técnicas de monitoramento e diagnóstico que nos foram apresentadas são fundamentais nesta nova fase que visa transformar, ao menos, parte deste grupo de doenças, em entidades curáveis. 


\section{Referências bibliográficas}

1. Hornig SJ, Rosenberg SA: The natural history of initially untreated low grade nonHodgkin's lymphoma. New EngJ Med. 1984. 311: 1471-1475.

2. Gallagher CJ, Lister TA: Follicular nonHodgkin's lymphoma. In: Baillière's Clinical Haematology. The Lymphomas. McElwain TJ and Lister TA Eds. Baillière Tindall, London. 1987. vol 1, pp. 141-155.

3. Kalter S, Holmes L, Cabanillas F: Long term results of treatment of patients with follicular lymphoma. Hematol Oncol. 1987. 5: 127-133.

4. Romaguera JE, McLaughlin P, North L, et al.: Multivariate analysis of prognostic factors in stage IV follicular low-grade lymphoma: a risk model. J Clin Oncol. 1991. 9: 762-769.

5. Kimby E and Mellsted H: ChlorambucilPrednisone (ChP) versus CHOP in symptomatic low grade lymphomas. Fifth Int Conf Malignant Lymphoma, Lugano 1993, abs. \# 65.

6. Coiffier B, Bastion Y, Berger F, Fellman P, Bryon PA: Prognostic factors in follicular Lymphomas. Sem Oncol. 1993. 20 suppl 5: 89-95.

7. Lopez-Guillermo A, Montserrat E, Bosch F, Terol MJ, Campo E, Rozman C: Applicability of the International Index for aggressive Lymphomas to patients with low-grade lymphoma. J Clin Oncol. 1994. 12: 1343-1348.

8. Freedman AS, Ritz J, Neuberg D, et al.: Autologous bone marrow transplantation in 69 patients with a history of low grade B cell non-Hodgkin's lymphoma. Blood. 1991. 77: 2524-2529.

9. Colombat Ph, Doandio D, Fouillard L, et al.: Value of autologous bone marrow transplantation in follicular lymphoma: A France autogreffe retrospective study of 42 patients. Bone Marrow Transplant. 1994. 13: 157-162.

10. Schouten HC, Colombat Ph, Verdonck LF, et al.: Autologous bone marrow transplantation for low grade non-Hodgkin's lymphoma: The European Bone Marrow Transplant Group experience. Ann Oncol. 1994. 5 (suppl.2): 147-149.

11. Cervantes F, Shu XO, McGlave PB, et al.: Autologous bone marrow transplantation for non-transforned low-grade non-Hodgkin's lymphoma. Bone Marrow Transplant 1995. 16: 387-392.
12. Bastion $\mathrm{Y}$, Brice $\mathrm{P}$, Haioun $\mathrm{C}$, et al.: Intensive therapy with peripheral blood progenitor cell transplantation in 60 patients with poorprognosis follicular lymphoma. Blood. 1995. 8: 3257-3262.

13. Haas R, Moos M, Karcher A, et al.: Sequential high dose therapy with peripheral-blood progenitor-cell support in low grade nonHodgkin's lymphoma. J Clin Oncol. 1994. 12: 1685-1692.

14. Corradini P, Astolfi M, Cherasco C, et al.: Molecular monitoring of minimal residual disease in follicular and mantle cell nonHodgkin's lymphomas treated with high-dose sequential (HDS) chemotherapy and PBPC autograft. Blood. 1997. 89: 724-31.

15. Hardingham JE, Kotasek D, Sage RE, et al.: Significance of molecular marker-positive cells after autologous peripheral-blood stem-cell transplantation for non-Hodgkin's lymphoma.

J Clin Oncol. 1994. 13: 1073-1079.

16. Moos M, Schulz R, Martin S, Haas R. The remission status before and the PCR status after high-dose therapy with peripheral blood stem cell support are prognostic factors for relapse-free survival in patients with follicular non-Hodgkin's lymphoma. Leukemia. 1998. 12: 1971-....

17. Maloney DG, Grillo-Lopez AJ, Bodkin DJ, et al. IDEC-C2B8: results of a Phase I multiple-dose trial in patients with relapsed non-Hogkin's lymphoma. J Clin Oncol. 1997. 15: 3266-74.

18. Czuczman MS, Grillo-Lopez AJ, Jonas C, et al. Chemoimmunoyherapy of low-grade lymphoma with the anti-CD2O antibody IDEC-C2B8 in combination with CHOP chemotherapy.

Cancer Invest. 1996. 14: 59-61.

19. McLaughlin P, Grillo-Lopez AJ, Link BK, et al. Rituximab chimeric anti-CD2O monoclonal antibody therapy for relapse indolent lymphoma: half of patients respond to a fourdose treatment program. J Clin Oncol 1997. 16: 2825-33.

20. Gianni AM, Magni M, Di Nicola M, et al. In vivo purging of circulating CD34+ progenitor cells in low-grade lymphoma with Rituximab and high-dose chemotherapy. Blood. 1998. 92 (suppl. 1): 481.

Recebido: 19/04/01

Aceito: 23/04/01 